\author{
Maria Lavrenova, \\ PhD (Candidate of Pedagogical Sciences), senior lecturer, \\ Nataliya Lalak, \\ PhD (Candidate of Pedagogical Sciences), associate professor, \\ Lyubov Fenchak, \\ PhD (Candidate of Pedagogical Sciences), associate professor, \\ Department of Theory and Methodology of Primary Education, \\ Mukachevo State University, \\ 26, Uzhhorodska Street, Mukachevo, Ukraine
}

\title{
PREPARING FUTURE TEACHERS FOR CREATING HEALTH PRESERVATION ENVIRONMENT AT PRIMARY SCHOOLS IN TERMS OF INCLUSIVE EDUCATION
}

The paper covers the aspects of preparing future primary school teachers for creating health preservation environment in inclusive education. It has been found that the students specialised in primary education lack skills of communicating with children with different nosologies and practical skills required for implementing health preservation technologies into the educational process of primary schools. However, the survey demonstrated that the students are ready to work with children with special educational needs. The means facilitating the optimisation of students' preparation for work with children under conditions of inclusive education have been described.

Keywords: inclusion, health preservation environment, future specialists, communication skills, health preservation technology.

Introduction. The entry of Ukraine into the European educational space, modernisation of primary education put forward new requirements for the training of future teachers. The modern design of the national education system is based on the principles of humanism, proactive approach, taking into account the dynamics of changes in domestic and international labor markets.

Nowadays, the global trend is the desire of the society to integrate people with special needs into the society. Under the influence of global processes of humanisation and integration, the modern Ukrainian society is also changing its attitude towards most vulnerable members, children with special needs, directing efforts of pedagogy and psychology to the understanding and cooperation. Inclusion is the requirement of time. For Ukraine, inclusive education is pedagogical innovation under implementation, so there are a lot of problems: the imperfections of the legal framework, architectural inaccessibility of schools, the need for additional financing, the lack of special textbooks, parents' negative attitude to their children, overloaded curricula, which are quite difficult to adapt to the needs of children with disabilities.

As a result, there is a matter of current interest concerning the process of providing inclusive education by highly qualified specialists who possess the techniques of positive motivation, professional capacity, humane and personal nature of the psychological impact on children, have high-quality psychological, pedagogical and methodological training on creating health preservation environment in schools. Today there is an urgent necessity to examine in detail the problems faced by each higher education institution that trains teachers and to think about seeking directions to update such training.
Modern psycho-pedagogical science has a number of studies dealing with the issue of preparing a modern teacher who has acquired a set of personal characteristics, and is characterised by the development of new, complex, integrated, professional personal formations. The latter include: professional mobility, pedagogical empathy, communicative creativity, health competence, etc. Analysis of recent publications has shown that the problem of modernisation of professional training system in higher educational institutions of Ukraine in coordination with global educational trends is investigated by Ya. Bolyubash, V. Kremen, S. Nikolayenko and others.

The views of such scientists as V. Bondar, N. Hontarovska, O. Horbatyuk, A.Kolupayeva, H. Kryvosheyeva appeared to be very valuable for our study. They dedicate their work to researching the problem of training future teachers to work in terms of inclusion and integration of children with disabilities into studying at secondary schools, their rehabilitation and adaptation to social norms. Over recent years, T. Berezhna, V. Bobrytska, Yu. Boychuk, T. Boychenko, O. Bondarenko, O. Vashchenko, V. Hryhorenko, V. Kozlova, N. Levinets, Yu. Naumenko, S. Omelchenko, V. Orzhekhovska, S. Svyrydenko, O. Svyrydiuk and others have been researching the problem of forming valeological culture and valeological education of future teachers. The analysis of the works made it possible to identify the main areas that need consideration while developing pedagogical conditions of creation and implementation of health preservation environment in education institutions.

The aim of the paper is to justify the peculiarities of forming health preservation environment by primary school teachers in educational institutions in terms of inclusion (on the example of Mukachevo State University). 
Objectives of the study:

1) to make a retrospective analysis of psychopedagogical and methodological literature on the issue;

2) to determine the content and justify the principles of the health preservation environment in educational institutions;

3) to identify and check factors that affect the process of professional formation of the future teachers (on the example of Mukachevo State University) concerning their work in health preservation environment of school in terms of inclusion.

Methods: theoretical analysis and synthesis of psychological, pedagogical, and scientific-methodological literature on the issue, classroom observation, talks, questionnaire, methods of mathematical statistics.

147 undergraduate students of the Faculty of Primary Education of Mukachevo State University participated in this pedagogical study.

Results:

The students were questioned and the data obtained indicated that:

- the low level of students' communicative competence while dealing with children with different nosology;

- insufficient level of theoretical knowledge and practical skills for implementation of healthy technology and forming health preservation environment in the educational process of the school in terms of inclusion;

- the formation of students' positive motivation, awareness of personal involvement into being healthy and keeping fit through introduction and diversification of forms and methods of teaching students with special educational needs.

Analysis of scientific papers written by psychologists, teachers, and doctors allowed us to define the content of health preservation environment that includes:

- organisation of educational process (compliance with state sanitary rules and regulations);

- favourable psychological background of classes (how the teacher communicates with his/her students), methods and forms of study;

- sanitation and hygiene of the educational environment (ventilation, temperature conditions, etc.);

- children's motor development (taking into account their age);

a balanced diet;

- education of cultural interaction with surroundings;

- developing a complex of various forms and methods of health preservation activity;

- technologisation that provides the availability of relevant teacher's knowledge and skills with implementation of health preservation pedagogical technologies into educational process of an educational institution.

In the formation of health preservation environment, such general principles are taken into consideration: humanism, child-centrism, accordance with the nature and culture, preventiveness, being consistent, active mediation in acquiring positive experience, openness [1].
Effectiveness of the work on the formation of students' health preservation competencies and preparation of future professionals for working in an inclusive environment depends on either higher education priorities or general ideology of an educational institution. In this aspect, a thorough educational and methodical preparation is carried out among students of Mukachevo State Unversity. We analysed the curricula for the specialty "Primary Education" and found out that there is a range of subjects in the system of university courses that contribute to students' preparation for creating health preservation environment in primary school in terms of inclusion. The first group consists of subjects, in which only a few sections and topics may disclose certain aspects of the abovementioned problem: "Didactics", "Theory and Methods of Education", "Developmental Psychology", "Pedagogical Skills", "Fundamentals of Psychological Diagnostics", "Basic Screen and Performing Arts", "Fundamentals of Screen and Stage Art", "Methods of Teaching Ukrainian Language", "Methods of Teaching Literary Reading", "Pedagogy of Family Upbringing", "Ethnopedagogy", "Safety", "Daycare Organisation".

The second group consists of such disciplines as: "Children's Anatomy and Physiology with the Basics of Genetics and Valeology", "Basic Medical Knowledge and Healthcare", "Methods of Studying the Fundamentals of Health in Primary School", "Physical Education with Studying Methodology", "Fundamentals of Valeology", "Principles of Inclusive Education". Their content and specific topics contribute to the formation of health preservation competence of future teachers.

The content of all these disciplines involves the study of issues regarding students' health preservation and formation of healthy lifestyle in the specialty "Primary Education". The course "Methods of Studying the Fundamentals of Health Care in Primary School" plays a significant role in deepening theoretical knowledge and improving students' practical and methodical skills. When studying this course, students are examining school curricula and textbooks on "Basics of Health Care" in primary school; develop questionnaires and tests to find out features of the formation of primary school children's healthy lifestyle; attend lessons in schools and analyse them; learn to make lesson plans, compile textbooks for the course "Basics of Health Care" in primary school. Quasi-professional activity is successfully used at the lessons and involves reproduction of elements of pedagogical work in the classroom, including conducting lessons with their further analysis and introspection. This type of work requires thorough future professional training, the rethinking of existing knowledge and promotes mastery of health preservation competence.

After studying the discipline "Principles of Inclusive Education" students should be able to practice the theoretical knowledge about organisation of the educational process in the CEI on inclusive basis, make up an individual educational programme and individual educational plan, organise cooperation with families who have chil- 
dren with disabilities, use effective methods of socialisation of children with different nosology.

At the lectures and workshops on this subject, students' attention is paid to the fact that inclusion in the educational institution is impossible without tolerance towards all participants of the educational process. This tolerance is an essential spiritually moral principle of civil society. Tolerance in school involves cooperation, the spirit of partnership; respect for human dignity; acceptance of another person as he/she is; the ability to put oneself in someone's place; recognition of the equality of others; tolerance for other people's opinions, beliefs and behaviour; rejection of evil and violence domination. In our opinion, providing emotional comfort is important in organising the educational process of primary school children. At the lessons and extracurricular activities, a teacher should try to form the personality traits that correspond to human values and coincide with the Bible ones.

Studying the disciplines "Methods of Teaching Ukrainian language" and "Methods of Teaching Literary Reading" involves solving a number of problems, including: mastering a system of knowledge about methods of teaching the Ukrainian language and literary reading, preparing highly qualified and competitive professionals in education in accordance with national and European standards.

The state education standard in the sector "Languages and Literature" for students with mental and physical disorders involves providing the appropriate level of communication skills, theoretical knowledge of the language, the formation and development of reading skills, speech and intellectual development. The most important compulsory subjects for primary schools are "Ukrainian Language" and "Literary Reading", because the level of their mastering largely determines the success of mastering other school subjects.

Lessons of the Ukrainian language and literary reading play an important role in promoting a healthy lifestyle among children in grades 1-4. They help supplement students' knowledge about their own health, raise the need to keep fit. For spelling tests, training dictations, and reading, it is advisable to choose the texts that contribute to the children's healthy lifestyle formation, for example: "Good Fruit and Vegetables", "Nutrition", "Food is the Source of Energy", "The Sun, Air and Water", "Keeping Fit", "My Daily Routine", "I am at Home", "Activities", "A Clean Source", "Useful and Bad Habits".

The analysis of psychological and methodical literature, advanced pedagogical experience leads us to conclude that in primary school, it is advisable to use a variety of visual and technical means, modern innovative methods and forms of work, in order to increase children's physical activity at the lessons. For example, "Rotating Three", "Aquarium", work in pairs and other exercises that involve students' moving from one place to another.

Due to prolonged repetitive work in the classroom, where students almost do not move, their attention gets weaker and the level of their perception reduces dramatically. Doing exercises in the classroom for the purpose of physical relaxation and switching children's attention from one activity to another affect positively the absorption of new material. In our opinion, there are the following effective motor activities at the lessons:

- motion exercises involving counting and games;

- motion exercises and imitating poetic texts;

- exercises for eyes;

- exercises for fingers.

During the research, the respondents noted that seminars and workshops at universities should be conducted as role-playing and communication games, social and psychological training, briefings, intellectual auctions. Innovative forms help to solve educational tasks, raise awareness of all participants of the educational process, preserve health and form communicative competence in dealing with children with special educational needs.

Forms of work are interrelated with either methods or techniques of pedagogical influence, or ways of teacher and pupils' cooperation, which has impact on consciousness, feelings, will, behaviour and relationships. Active methods of health preservation play a priority role, are based on a democratic style of interaction and promote critical thinking, initiative and creativity. Moreover, it is advisable to use traditional methods: conversations, games, literary and musical compositions, sports, explanations, conviction, positive and negative examples, methods of developing habits, exercise technique, control and self-control, forming public opinion, etc., as well as innovative ones: methods of "educational therapy", namely self-regulation, selfteaching; pedagogical workshops, reflection. These methods create certain unity and complementarity.

The organisation of health preservation activity in educational institutions includes work with the teaching staff, students and parents. Therefore, the process of professional training on the subject "Pedagogy of Family Education" form students' skills of providing pedagogical consultation, lectures to parents, workshops, discussions, concerts, readings, family reports, minilectures, which helps to organise health preservation environment in inclusive education.

The next direction to solve the above-mentioned problems is organisation of extracurricular educational work with future primary school teachers. Students of Mukachevo State University participate in organising cultural and informational events on various topics concerning health preservation:

- conferences: "Sports Games and their Positive Potential", "Caring for the Future", "Alcohol and its Effects on Health", "Personal Responsibility for Health", "Safe Environment and Protective Public Services", "Communication and Health";

- meetings at round tables: "Motor Activity and its Impact on Adolescent Development", "Life Rhythm Organisation. Daily Routine"," Sleep and Health", "Activities", "Ex- 
ercises and Procedures to Maintain and Promote Health", "Keeping Fit. Its Importance to Health";

lessons-trainings: "Formula of Healthy Lifestyle", "Steps for Physical Development", " Make your Choice in Favour of Health", "Formula of Safe Life", "The Rules of Relationships", "What Should we Know about HIV/AIDS";

frank conversations: "Know yourself', "What Promotes Understanding between People", "Individual Peculiarities of a Person", "My Participation in Maintaining Health of my Family Members", "Communication with Adults and Peers", "About Senses and Compassion";

- flash mobs, debates, briefings, meetings, discussions, Socratic dialogue and hotline.

These measures included the individualisation of organisational forms, methods of education through the development of personal qualities of each student. It has already become a tradition for students of Mukachevo State University to do volunteering. Future specialists visit boarding institutions and inclusive classes. This kind of activity forms the communicative competence, helps to acquire practical skills of working with children with special educational needs. Every year our students participate in charity events at Easter and Christmas: "A gift from St. Nicholas", "A Green Lawn", "Gift a smile to a child".

$92 \%$ of students indicated that the use of such unconventional forms of extracurricular work during their professional training is effective and appropriate.

Teaching practice takes a prominent place among many factors that determine the success of a modern teacher. Experience shows us that only in practical conditions the primary school orientation can be changed into the formation of persistent skills. During practice, future teachers develop and conduct educational activities and lessons that promote healthy lifestyle, prevention of deviant behaviour, interper-

\section{ЛIТЕРАТУРА}

1. Бережна T. I. Моделювання здоров'язбережувального середовища загальноосвітнього навчального закладу : обгрунтування структури і критеріїв / Т. І. Бережна // Рідна школа. - №1 . - С.37-41.

2. Бобрицька В. І. Формування здорового способу життя у майбутнього вчителя : [монографія] / В. I. Бобрицька. - Полтава : Скайтек, 2006. - 431 с.

3. Бондар В. І. Інклюзивне навчання та підготовка педагогічних кадрів для його реалізації / В. І. Бондар // Науковий часопис НПУ імені М. П. Драгоманова. - Серія 19. Корекційна педагогіка та психологія. - Вип.15. - 2010. - С.39-42

4. Колупаєва А. Інклюзивна освіта в контексті реалій сьогодення / А. Колупаєва // Практика управління закладом освіти. - 2010. - № 4. - С. 52-56.

5. Лавренова М. В. Підготовка майбутніх учителів до формування орфоепічних умінь українського літературного мовлення молодших школярів в умовах діалектного середовища / М. В. Лавренова // Професійна підготовка майбутнього педагога в умовах sonal cultural education and interethnic relationship. Programmes for pedagogical practices that are based on the principles of transparency, interdisciplinarity, and professional orientation provides students with an opportunity to undertake the following types of practices: extracurricular educational activities, helping children to adjust to the first days at school, test lessons, practice in summer camps, psychological, pedagogical training, and pre-graduation practice.

Pedagogical practice as an integral component of methodical training of future primary school teachers is of the main ways of forming their personal experience and willingness to create health preservation environment in inclusive classes.

Conclusions. Today, every child deserves living life to the full, in conditions where his/her dignity is respected, and the development of his/her self-confidence is promoted; all children have the right to special care, good education, active social and cultural life.

It has been concluded that preparation of future teachers for creating health preservation environment in primary schools in terms of inclusion depends on either educational system of a university or the individual efforts made by each member of the educational process.

Mukachevo State University helps young professionals to fulfill their educational and functional up-todate responsibilities through accumulating traditions and modern achievements of science and practice with the purpose of implementing modern approaches, feeling familiar with the information space and becoming a competitive employee.

The article has not covered all the aspects of the problem raised. The issues related to practical aspects of health preservation environment in primary school in terms of inclusion on the scientific and methodological levels still require further study.

сучасної освітньої парадигми : монографія / За заг. ред. д.пед.н. Товканець Г. В. - К. : КондорВидавництво, 2015. - С.52-60.

6. Lavrenova M.V. Training of primary school teachers for the Ukrainian language lessons in inclusive learning environment / M. V. Lavrenova, N. V. Lalak // Teaching science : theory, history, innovative technologies. - 2016. - №1 (55). - C. 94-102.

7. Лалак Н. В. Шляхи впровадження інклюзії в роботу загальноосвітніх навчальних закладів / Н. В. Лалак // Науковий вісник Ужгородського національного університету. Серія : «Педагогіка. Соціальна робота». - 2012. - Вип.23. - С.107-109.

8. Фенчак Л. М. Теоретико-методологічний підхід до формування здоров'язберігаючої компетентності майбутніх педагогів / Л. М. Фенчак // Щомісячний науково-педагогічний журнал Дрогобицького державного педагогічного університету ім. І. Франка «Молодь і ринок». - Випуск №1(132). - С. 92-97. 


\section{REFERENCES}

1. Berezhna, T. I. (2016). Modeliuvannia zdoroviazberezhuvalnoho seredovyshcha zahalnoosvitnoho navchalnoho zakladu: obgruntuvannia struktury i kryteriiv [Forming health preservation environment in an educational institution: substantiation of the structure and criteria]. Ridna shkola - Native school, 1, 37-41 [in Ukrainian].

2. Bobrytska, V. I. (2006). Formuvannia zdorovoho sposobu zhyttia u maybutnoho vchytelia [Formation of healthy lifestyle of future teachers]. Poltava: Skaytek [in Ukrainian].

3. Bondar, V. I. (2010). Inkliuzyvne navchannia ta pidhotovka pedahohichnykh kadriv dlia yoho realizatsii [Inclusive education and preparing teachers for its implementation]. Naukovyi chasopys NPU imeni M. P. Drahomanova - Scientific journal of the National Pedagogical Dragomanov Univeristy, 15, 39-42. Kyiv [in Ukrainian].

4. Kolupaieva, A. (2010). Inkliuzyvna osvita v konteksti realii sohodennia [Inclusive education in today's realities] Praktyka upravlinnia zakladom osvity - Practice of educational institution management, 4, 52-56 [in Ukrainian].

5. Lavrenova, M. V. (2015). Pidhotovka maibutnikh uchyteliv do formuvannia orfoepichnykh umin ukrainskoho literaturnoho movlennia molodshykh shkolariv v umovakh dialektnoho seredovyshcha [Preparation of future teachers to form junior school pupils' orphoepic skills of Ukrainian literary language in dialect environment]. Profesiina pidhotovka maibutnoho pedahoha $v$ umovakh suchasnoi osvitnoi paradyhmy: monohrafia Professional training of future teachers in modern educational paradigm: monograph. Kyiv: KondorVydavnytstvo [in Ukrainian].

6. Lavrenova, M. V., \& Lalak, N. V. (2016). Training of primary school teachers for the Ukrainian language lessons in inclusive learning environment. Teaching science: theory, history, innovative technologies, 1(55), 94102. Sumy [in English].

7. Lalak, N. V. (2012). Shliakhy vprovadzhennia inkliuzii $\mathrm{v}$ robotu zahalnoosvitnikh navchalnykh zakladiv [The ways of implementing inclusion into the work of comprehensive schools]. Naukovyi visnyk Uzhhorodskoho natsionalnoho universytetu. Seria: «Pedahohika. Sotsialna robota» - Scientific Bulletin of the Uzhgorod National University, 23, 107-109 [in Ukrainian].

8. Fenchak, L. M. (2016). Teoretykometodolohichnyi pidkhid do formuvannia zdoroviazberihaiuchoi kompetentnosti maibutnikh pedahohiv [Theoretical and methodological approach to the formation of healthy preservation competence of future teachers]. Shchomisiachnyi naukovo-pedahohichnyi zhurnal Drohobytskoho derzhavnoho pedahohichnoho universytetu im. I. Franka «Molod i rynok»-Scientific and educational journal of Franko Drohobych State Pedagogical University «The Youth and the Market», 1(132), 92-97 [in Ukrainian].

\section{ПІДГОТОВКА МАЙБУТНІХ ПЕДАГОГІВ ДО СТВОРЕННЯ ЗДОРОВ'ЯЗБЕРЕЖУВАЛЬНОГО СЕРЕДОВИЩА ПОЧАТКОВОЇ ШКОЛИ В УМОВАХ ІНКЛЮЗІЇ}

Статтю присвячено проблемі підготовки майбутніх учителів початкової школи до створення здоров'язбережувального середовища в умовах інклюзії. Авторами, на основі анкетування студентів, з'ясовано, що майбутні педагоги готові працювати 3 дітьми з особливими освітніми потребами. Визначено, що студентам бракує комунікативних навичок у спілкуванні з дітьми з різними нозологіями та практичних умінь щодо впровадження здоров'язбережувальних технологій у навчально-виховному процесі початкової школи. Розглянуто результати досліджень багатьох науковців, які засвідчують, що розумовий, емоційний і соціальний розвиток дітей з психофізичними вадами прямо залежить від позитивного ставлення до них, їх розуміння та прийняття педагогами, батьками і здоровими дітьми. Проведено аналіз навчальних дисциплін спеціальності «Початкова освіта», які своїм змістом сприяють підготовці студентів до створення такого навчального середовища: «Дидактика», «Теорія та методика виховання», «Вікова психологія», «Педагогічна майстерність», «Основи психодіагностики», «Основи екранного та сценічного мистецтва», «Методика навчання української мови», «Методика навчання літературного читання», «Педагогіка сімейного виховання», «Етнопедагогіка», «Безпека життєдіяльності», «Організація групи продовженого дня», «Анатомія та фізіологія дітей з основами генетики і валеології», «Основи медичних знань та охорони здоров'я», «Методика вивчення основ здоров'я в початковій школі», «Фізична культура $з$ методикою навчання», «Основи валеології», «Основи інклюзивної педагогіки». Визначено роль позааудиторної роботи, що передбачає індивідуалізацію організаційних форм, методів виховання через розвиток особистісних якостей кожного студента. У процесі такої роботи формується комунікативна компетен- 
тність, студенти набувають практичних навичок роботи 3 дітьми з особливими освітніми потребами та здійснюють інформаційно-просвітницьку діяльність серед молодших школярів та їхніх батьків. 3'ясовано, що важливе місце серед багатьох факторів, що визначають успіх підготовки сучасного вчителя посідає педагогічна практика, адже тільки в практичних умовах школи первинне орієнтування може перейти у стійкі професійні навички. Під час практик майбутні вчителі розробляють і проводять виховні заходи й уроки, які сприяють формуванню здорового способу життя, профілактиці девіантної поведінки, вихованню культури між статевих і міжетнічних стосунків.

Ключові слова: інклюзія, здоров’язбережувальне середовище, майбутні фахівці, комунікативні навички, здоров'язбережувальні технології.

Мария Васильевна Лавренова,
кандидат педагогических наук, стариий преподаватель,
Наталья Владимировна Лалак,
кандидат педагогических наук, доцент,
Любовь Михайловна Фенчак,
кандидат педагогических наук, дочент,
кафедра теории и методики начального образования,
Мукачевский государственньй университет,
ул. Ужгородская, 26, г. Мукачево, Украина

\section{ПОДГОТОВКА БУДУЩИХ ПЕДАГОГОВ К СОЗДАНИЮ ЗДОРОВЬЕСБЕРЕГАЮЩЕЙ СРЕДЫ НАЧАЛЬНОЙ ШКОЛЫ В УСЛОВИЯХ ИНКЛЮЗИИ}

Статья посвящена проблеме подготовки будущих учителей начальной школы к созданию здоровьесберегающей среды в условиях инклюзии. На основе анкетирования студентов авторами выяснено, что будущие педагоги готовы работать с детьми с особыми образовательными потребностями. Определено, что студентам не хватает коммуникативных навыков в общении с детьми с различными нозологиям и практических умений по внедрению здоровьесберегающих технологий в учебно-воспитательный процесс начальной школы. Рассмотрены результаты исследований многих ученых, которые свидетельствуют, что умственное, эмоциональное и социальное развитие детей с психофизическими недостатками напрямую зависит от позитивного отношения к ним, понимания их и принятия педагогами, родителями и здоровыми детьми. Проведен анализ учебных дисциплин специальности «Начальное образование», которые своим содержанием способствуют подготовке студентов к созданию такой учебной среды: «Дидактика», «Теория и методика воспитания», «Возрастная психология», «Педагогическое мастерство», «Основы психодиагностики», «Основы экранного и сценического искусства», «Методика обучения украинскому языку», «Методика обучения литературному чтению», «Педагогика семейного воспитания», «Этнопедагогика», «Безопасность жизнедеятельности», «Организация группы продленного дня», «Анатомия и физиология детей с основами генетики и валеологии», «Основы медицинских знаний и охраны здоровья», «Методика изучения основ здоровья в начальной школе», «Физическая культура с методикой обучения», «Основы валеологии», «Основы инклюзивной педагогики». Определена роль внеаудиторной работы, которая предусматривает индивидуализацию организационных форм, методов воспитания через развитие личностных качеств каждого студента. В процессе такой работы формируется коммуникативная компетентность, студенты приобретают практические навыки в работе с детьми с особыми образовательными потребностями и осуществляют информационно-просветительскую деятельность среди младших школьников и их родителей. Выяснено, что важное место среди многих факторов, определяющих успех подготовки современного учителя, занимает педагогическая практика, ведь только в практических условиях школы первичное ориентирование может перейти в устойчивые профессиональные навыки. Во время практик будущие учителя разрабатывают и проводят воспитательные мероприятия и уроки, способствующие формированию здорового образа жизни, профилактике девиантного поведения, воспитанию культуры межполовых, межэтнических отношений.

Ключевые слова: инклюзия, здоровьесберегающая среда, будущие специалисты, коммуникативные навыки, здоровьесберегающие технологии.

Подано до редакичії 19.10.2016

Рецензент: д. пед. н., проф. Г. В. Товканец̧ь 